\title{
The Application of Thermal Decomposition for Determination of Carbonate Acid-Neutralising Capacity for Improved Acid Mine Drainage Prediction
}

\author{
Andrea R. Gerson ${ }^{1, *}$, Paul Weber ${ }^{2}$, Roger St. C. Smart ${ }^{1}$, George Levay ${ }^{3}$, Mike Hutton-Ashkenny ${ }^{4}$ \\ and Rosalind Green ${ }^{5}$ \\ Blue Minerals Consultancy, Wattle Grove 7109, Australia; roger@bluemineralsconsultancy.com.au \\ 2 Mine Waste Management, Christchurch 8440, New Zealand; paul.weber@minewaste.com.au \\ 3 Levay \& Co. Environmental Services, Edinburgh 5106, Australia; george.levay@levayandco.com \\ 4 Rio Tinto Research \& Technical Development Centre, Melbourne 3083, Australia; \\ Mike.Hutton-Ashkenny@riotinto.com \\ 5 Rio Tinto, Copper \& Diamonds, Brisbane 4000, Australia; Rosalind.Green@riotinto.com \\ * Correspondence: andrea@bluemineralsconsultancy.com.au
}

Citation: Gerson, A.R.; Weber, P.; Smart, R.S.C.; Levay, G.; Hutton-Ashkenny, M.; Green, R. The Application of Thermal Decomposition for Determination of Carbonate Acid-Neutralising Capacity for Improved Acid Mine Drainage Prediction. Minerals 2021, 11, 1181. https://doi.org/10.3390/ $\min 11111181$

Academic Editor: Anita

Parbhakar-Fox

Received: 17 September 2021

Accepted: 18 October 2021

Published: 25 October 2021

Publisher's Note: MDPI stays neutral with regard to jurisdictional claims in published maps and institutional affiliations.

Copyright: (c) 2021 by the authors. Licensee MDPI, Basel, Switzerland. This article is an open access article distributed under the terms and conditions of the Creative Commons Attribution (CC BY) license (https:/ / creativecommons.org/licenses/by/ $4.0 /)$.

\begin{abstract}
This study developed an industry-applicable, thermal decomposition methodology for quantification of carbonate mineral acid neutralisation capacity $\left(\mathrm{ANC}_{\text {therm-carb }}\right)$ for waste rock, tailings, and other mined materials. Standard titration-based methods for ANC can be compromised due to contributions from silicate minerals, ion exchange, Fe-rich carbonates, and other transition metal carbonates. $\mathrm{C}$ emission $\left(\mathrm{CO}_{2}\right.$ and $\left.\mathrm{CO}\right)$ was measured using IR in a $\mathrm{N}_{2}$ atmosphere. $\mathrm{C}_{\text {neut }}(\mathrm{wt} \%)$ was calculated using the $\mathrm{C}$ emission at 800 or $1000^{\circ} \mathrm{C}$ minus the $\mathrm{C}$ emission at 400,450 or $500{ }^{\circ} \mathrm{C}$ and the weight of sample prior to decomposition (Equation (2) of this manuscript). This value was then input into Equation (3) of this manuscript to calculate $\mathrm{ANC}_{\text {therm-carb }}$. Good correlation of $\mathrm{ANC}_{\text {therm-carb }}$ for single-mineral carbonates with $\mathrm{ANC}_{\text {calc }}$, calculated from bulk assay concentrations for $\mathrm{Mg}, \mathrm{K}, \mathrm{Na}, \mathrm{Ca}$, and $\mathrm{Mn}$, was achieved. Thereafter, 18 waste rock samples were examined, resulting in the correlation of $\mathrm{ANC}_{\text {therm-carb }}$ versus non-standard $\mathrm{ANC}_{\text {titrate-carb }}$ (titration methodology adapted to focus on carbonate neutralisation only) with $\mathrm{R}^{2}=0.96$. This correlation is valid for samples containing both non-neutralising carbonates (siderite) and sources of neutralisation arising from non-carbonates (Mg-clay) within this waste rock system. Typically, mining operations use total C measurements for assessment of carbonate neutralisation potential in the block and mining model. This method provides an effective means to cheaply analyse for carbonate neutralisation potential with assignment of potentially acid-forming and non-acid-forming blocks to waste rock cells, etc.
\end{abstract}

Keywords: acid mine drainage; mine waste rock characterisation; acid neutralisation capacity; mineral carbonates; thermal decomposition

\section{Introduction}

Acid mine drainage (AMD) is an internationally-recognised environmental issue arising, primarily, from the exposure of pyrite $\left(\mathrm{FeS}_{2}\right)$ to weathering, resulting in the formation of acid and simultaneous metalliferous drainage [1]. One of the first steps to determine if AMD is likely is the geochemical characterisation of mine waste materials. For this characterisation process, standardised, internationally-recognised methods are applied [2]. Many of these acid base-accounting (ABA) standardised tests have been reviewed in [3]. Often, the first step in ABA is the definition of both the maximum potential acid (MPA) generation and the acid neutralisation capacity (ANC) for a specific material. The net acid production potential (NAPP) is then defined as MPA minus ANC. If this value is positive, then the waste is likely to be acid generating. This initial assessment is, thereafter, complemented by other analyses such as net acid generation testing, neutralisation potential ratio (NPR) determination and kinetic leach columns [4,5]. A NPR assessment in 
block/mining models is often used to assign acid-generating material, but during initial or detailed characterisation studies, it is also common to explore more broadly with AMIRA International Ltd classifications, etc. [4,5].

The standard approach for definition of ANC is by titration in the Sobek test [4], the results from which often depend on subjective initial fizz rating tests to determine the amount of acid to be added for full carbonate dissolution, and subjective times for reactions to occur after carbonate dissolution on back-titration to $\mathrm{pH}$ 7. Carbonate minerals can be subjectively divided into three categories under Sobek test conditions:

(i) Those that provide acid neutralisation in the ratio of $2 \mathrm{H}^{+}$per carbonate dissolved. These include calcite $\left(\mathrm{CaCO}_{3}\right)$, magnesite $\left(\mathrm{MgCO}_{3}\right)$ and dolomite $\left.(\mathrm{Mg}, \mathrm{Ca})_{2}\left(\mathrm{CO}_{3}\right)_{2}\right)$. Copper carbonate minerals, e.g., malachite $\left(\mathrm{Cu}_{2} \mathrm{CO}_{3}(\mathrm{OH})_{3}\right)$, azurite $\left(\mathrm{Cu}_{3}\left(\mathrm{CO}_{3}\right)_{2}(\mathrm{OH})_{2}\right)$, and manganese carbonate minerals, e.g., rhodochrosite $\left(\mathrm{MnCO}_{3}\right)$, also fall into this category, as the aqueous $\mathrm{Cu}$ and $\mathrm{Mn}$ do not hydroxylate at neutral $\mathrm{pH}$ (unless present at very high concentrations). Released metals such as $\mathrm{Mn}$ and $\mathrm{Cu}$ from carbonate minerals are acknowledged as potential contributors to neutral metalliferous drainage (NMD) but this is not discussed further in this work. However, this needs to be considered as part of any AMD risk assessment process.

(ii) Carbonate minerals that produce less neutralisation, for instance, ferroan dolomite $\left(\mathrm{Ca}\left(\mathrm{Mg}_{\mathrm{x}}, \mathrm{Fe}_{(1-\mathrm{x})}\right)\left(\mathrm{CO}_{3}\right)_{2}\right)$ and ankerite $\left.\mathrm{Ca}\left(\mathrm{Mg}_{\mathrm{x}}, \mathrm{Mn}_{\mathrm{y}}, \mathrm{Fe}_{(1-\mathrm{x}-\mathrm{y})}\right)\left(\mathrm{CO}_{3}\right)_{2}\right)$. For these minerals, the degree of neutralisation produced is dependent on the cations present that do not hydroxylate at neutral $\mathrm{pH}$, e.g., $\mathrm{Ca}^{2+}, \mathrm{Mg}^{2+}$ or $\mathrm{Mn}^{2+}$. In contrast, ferrous iron $\left(\mathrm{Fe}^{2+}\right)$ will oxidise to ferric iron $\left(\mathrm{Fe}^{3+}\right)$ and form a neutral hydroxylation complex releasing acid. Consequently, the maximum amount of neutralisation, $2 \mathrm{OH}^{-}$per carbonate, is decreased by the concentration of the Fe, i.e., $1-x$ or $1-x-y$. The same concept applies to any other cations within these mineral frameworks that hydroxylate at neutral $\mathrm{pH}$.

(ii) Carbonate minerals that do not produce any net neutralisation on dissolution. The most common of these minerals is siderite $\left(\mathrm{FeCO}_{3}\right)$. The lack of neutralisation potential for siderite is now well acknowledged in the literature [6].

The presence of Fe-containing carbonate minerals can result in erroneously high ANC values in the standard Sobek ANC test due to the slow hydroxylation and precipitation of $\mathrm{Fe}^{3+}$ [6,7]; complete oxidation results in no net acid neutralisation (e.g., Equation (1) for siderite). Consequently, there is potential to inaccurately measure the ANC of iron-rich carbonate waste rocks. This can be rectified by the application of the modified Sobek test [7], wherein peroxide is added to ensure full oxidation and hydroxylation of the dissolved Fe but this can induce unrealistic reactions in some other minerals (e.g., pyrrhotite, chalcopyrite).

$$
\begin{aligned}
& \mathrm{FeCO}_{3(\mathrm{~s})}+3 \mathrm{H}^{+}+0.25 \mathrm{O}_{2} \rightarrow \mathrm{Fe}^{3+}+\mathrm{H}_{2} \mathrm{CO}_{3}+0.5 \mathrm{H}_{2} \mathrm{O} \\
& \mathrm{Fe}^{3+}+3 \mathrm{H}_{2} \mathrm{O} \rightarrow \mathrm{Fe}(\mathrm{OH})_{3}+3 \mathrm{H}^{+}
\end{aligned}
$$

The ANC titration process is also known to capture a proportion of neutralisation from fast-reacting silicates (e.g., chlorite, Table 18 in [8]). There exists disagreement concerning the usefulness of neutralisation arising from silicate dissolution [9] or ion exchange [10] in terms of extents and rates, e.g., too slow from silicates and too fast from ion exchange. It is also noted that many transition metal cations are present in solution at neutral $\mathrm{pH}$ as demonstrated by the issue of NMD and hence any assumption of their complete precipitation at neutral $\mathrm{pH}$ following an ANC back-titration is clearly incorrect. It is therefore desirable to develop a robust automated method for identification and quantification of carbonate mineralogies that do, and do not, contribute to ANC.

Considerable analysis has been carried out on thermal decomposition properties of mineral carbonates [11-15] but only a limited number of studies have examined the application of thermal decomposition for determination of carbonate ANC. Hammack [16] used evolved gas analysis in a $10 \% \mathrm{O}_{2}$ and $90 \% \mathrm{~N}_{2}$ atmosphere and concluded that bicarbonates gave rise to $\mathrm{CO}_{2}$ peaks in the range of $100-200{ }^{\circ} \mathrm{C}$, the transition metal carbonates in the range of $220-520^{\circ} \mathrm{C}$, and the alkaline earth carbonates between $220-440{ }^{\circ} \mathrm{C}$ and $520-660{ }^{\circ} \mathrm{C}$. 
However, the number of carbonate phases examined was limited to sodium bicarbonate, manganous carbonate and calcium carbonate.

A controlled-atmosphere programmed-temperature oxidation (CAPTO) apparatus [17] was used for analysis of emission of $\mathrm{CO}_{2}, \mathrm{H}_{2} \mathrm{O}, \mathrm{SO}_{2}$ and $\mathrm{NO}_{2}$ from coals [18] but the focus of this study was the characterisation of the coals and not the determination of ANC. This was also the case for [19] which focused on how magnesite, siderite, calcite, dolomite and ankerite affected the calorific capacity of coal.

More recently, a methodology based on selective thermal decomposition of different carbonates (calcite, dolomite, and siderite) to provide well-resolved carbon dioxide evolutions has been tested [20]. The method used controlled gas flow and temperature ramping in a modified LECO analysis with continuous Fourier-transform infrared (FTIR) $\mathrm{CO}_{2}$ analysis of gas evolved. This approach successfully determined the concentrations of alkaline earth- and transition metal-carbonates in coal over-burden samples. Thereafter, a methodology was developed using thermogravimetric and differential analysis for the quantification of siderite, calcite and dolomite [21] but this study was not focused on the determination of carbonate ANC. A thermal procedure, therefore, potentially provides an alternative direct method of correctly determining carbonate neutralisation capacity in mine rock and tailings wastes but requires development for application to a greater range of carbonate minerals and non-coal ore bodies.

The potentially important, unique role for the thermal decomposition method may be the analysis of problematic samples shown to contain significant siderite and other nonneutralising carbonates to give correct information on ANC available from carbonates in the waste. In the study described herein, we have sought to adapt the method as given in [20] to develop an industry-applicable approach for carbonate ANC determination, avoiding issues of slow-reacting carbonates and non-neutralising carbonates. Single-mineral samples were used to validate and refine the process, followed by the assessment of waste rock samples from a mine project site.

\section{Materials and Methods}

\subsection{Mineralogy and Bulk Assay}

Quantitative X-ray diffraction analysis was carried out on the 'single' mineral carbonate samples. Powder X-ray diffraction data were collected using a Bruker D8 Advance Eco X-ray diffractometer (Bruker, Billerica, MA, USA) with Co K $\alpha$ radiation $(\lambda=1.7902 \AA$ ) at $35 \mathrm{kV}$ and $28 \mathrm{~mA}$, across the $2 \theta$ range $10-90^{\circ}$ with a step size of $0.02^{\circ}$. A Fe filter was used to reduce the Co K $\beta$ X-ray emission intensity. Each sample for XRD analysis was micronized using a micronizing mill (XRD-Mill, McCrone, Westmont, IL, USA). Phase identification was carried out using the Diffrac. EVA software (Bruker, Billerica, MA, USA; Version 3.0) with application of the ICDD PDF-4+ database (International Centre for Diffraction Data, Newtown Square, PA, USA). Corundum (15 wt \%) was added to each sample as an internal standard and for quantification of the amorphous/unknown component. Quantitative phase analysis was performed using the computer program TOPAS (Bruker; Version 4.2). Uncertainties of the resulting XRD analysis at the $95 \%$ confidence level are estimated to be $\pm \chi^{0.35}$ where $\chi$ is the $w \mathrm{t} \%$ of a given crystalline phase [22]. The amorphous/unknown components were determined to be negligible and have not been included in Table 1 (i.e., the sum of the $\mathrm{wt}^{\mathrm{t}} \%$ mineral phase for each sample is $100 \mathrm{wt} \%$ ).

Quantitative mineralogical characterisation, of the mine site project samples, was carried out using scanning electron microscopy (SEM) combined with automated mineral liberation analysis (MLA; FEI Quanta 600 Mineral Liberation Analyser, at $15 \mathrm{kHz}$ at 90k counts s ${ }^{-1}$ ) at Rio Tinto's Research and Technical Development Centre (Melbourne, Australia). This system utilises two X-ray-collecting silicon drift detectors (Bruker XFlash 6130 detectors) which measure spectra expressed as normalised counts per second per channels along the keV scale. The MLA measurement type utilised during this project was the GXMAP measurement mode. Samples were prepared as 8 individual carbon-coated 
polished blocks for each waste rock sample using representative splits ( $>200 \mathrm{~g})$ of material available from the coarse rejects $(-2 \mathrm{~mm})$ from drill core assay sample preparation.

Bulk assays were carried out using mixed acid digestion followed by ICP-OES (inductively coupled plasma-optical emission spectroscopy) detection. Total C was measured by LECO.

Table 1. Quantitative XRD analyses (wt \%) of the carbonate mineral samples. Where a specific mineral was not identified as being present the cell has been left empty.

\begin{tabular}{|c|c|c|c|c|c|c|c|c|c|}
\hline $\begin{array}{c}\text { Mineral } \\
\text { Phase }\end{array}$ & $\begin{array}{c}\text { Standard } \\
\text { Stoichiometry }\end{array}$ & Magnesite & Siderite & Rhodochrosite & Dolomite & Calcite & Azurite & Malachite & Ankerite \\
\hline Quartz & $\mathrm{SiO}_{2}$ & 0.2 & 2.5 & 4.3 & 0.5 & 0.2 & 0.8 & 0.3 & 44 \\
\hline $\begin{array}{l}\text { Calcite } \\
\text { Dolomite }\end{array}$ & $\begin{array}{c}\mathrm{CaCO}_{3} \\
\mathrm{CaMg}\left(\mathrm{CO}_{3}\right)_{2}\end{array}$ & 17.9 & & & 1.1 & 99.8 & & & 76 \\
\hline $\begin{array}{l}\text { Dolomite } \\
\text { Rhodochrosite }\end{array}$ & $\mathrm{MnCO}_{3}$ & & & 95.7 & & & & & \\
\hline $\begin{array}{l}\text { Azurite } \\
\text { Magnesite }\end{array}$ & $\begin{array}{c}\mathrm{Cu}_{3}\left(\mathrm{CO}_{3}\right)_{2}(\mathrm{OH})_{2} \\
\mathrm{MgCO}_{3}\end{array}$ & 81.9 & & & & & 99.2 & & \\
\hline Malachite & $\mathrm{Cu}_{2} \mathrm{CO}_{3}(\mathrm{OH})_{2}$ & & & & & & & 99.7 & \\
\hline Siderite & $\mathrm{FeCO}_{3}$ & 0.1 & 91.5 & & & & & & 27.3 \\
\hline Ankerite & $\mathrm{Ca}\left(\mathrm{Fe}^{2+}, \mathrm{Mg}\right)\left(\mathrm{CO}_{3}\right)_{2}$ & & & & & & & & 7.2 \\
\hline $\begin{array}{l}\text { Hematite } \\
\text { Sphalerite }\end{array}$ & $\begin{array}{l}\mathrm{Fe}_{2} \mathrm{O}_{3} \\
\mathrm{ZnS}\end{array}$ & & 5.9 & & & & & & 138 \\
\hline
\end{tabular}

\subsection{Acid Neutralisation Capacity by Titration}

\subsubsection{ANC Titration Methodology (1) $-\mathrm{ANC}_{\text {titrate-all }}$}

The objective of this methodology is to capture all measurable ANC, i.e., carbonate, silicate, and ion exchange, while ensuring non-neutralising carbonates, e.g., siderite, are not included. The methodology (1) titration protocol followed the standard AMIRA Test Handbook [4] methodology with 2 drops of $30 \% \mathrm{H}_{2} \mathrm{O}_{2}$ solution added after back-titration to $\mathrm{pH} 4.5$, prior to further titration to $\mathrm{pH}$ 7. In a modification of this methodology (developed by Levay and Co Environmental Services-unpublished), if the $\mathrm{pH}$ of the solution had not equilibrated within 1 min a further 2 drops of $\mathrm{H}_{2} \mathrm{O}_{2}$ solution was added and so forth until the $\mathrm{pH}$ was equilibrated. For the siderite 'single-mineral' sample, a total of 6 drops of $\mathrm{H}_{2} \mathrm{O}_{2}$ solution was added and for the ankerite 'single-mineral' sample 4 drops of $\mathrm{H}_{2} \mathrm{O}_{2}$ was added. For all other minerals only 2 drops $\mathrm{H}_{2} \mathrm{O}_{2}$ solution were required.

\subsubsection{ANC Titration Methodology (2)- $\mathrm{ANC}_{\text {titrate-carb }}$}

This methodology was applied only to waste rock samples and is the same as methodology (1) except for a change in the target digestion $\mathrm{pH}$ prior to back-titration, from $0.8-1.5$ to $1.5-2.0$, and back-titration to $\mathrm{pH} 8.3$ rather than $\mathrm{pH}$ 7. The change in target digestion $\mathrm{pH}$ was made with the purpose of reducing silicate and ion-exchange neutralisation so that mostly only carbonate neutralisation is measured. The increased final $\mathrm{pH}$ after back-titration is to ensure the full hydroxylation of metal cations (e.g., $\mathrm{Cu}^{2+}$ and $\mathrm{Zn}^{2+}$ ) other than $\mathrm{Na}^{+}, \mathrm{K}^{+}, \mathrm{Mg}^{2+}$ and $\mathrm{Ca}^{2+}$, so that these do not contribute to the measured ANC.

\subsection{Thermal Decomposition}

A feed single-carbonate mineral sample $(100 \mathrm{mg},<75 \mu \mathrm{m})$ was placed in a preheated quartz tube ( $3 \mathrm{~cm}$ diameter) furnace at each of the temperatures of 400, 500,600,700, and $800{ }^{\circ} \mathrm{C} . \mathrm{CO}_{2}$ emission was then measured for 30 min using IR detection (TSI 7575 Q-Trak, with 982 IAQ probe). A 30 min decomposition duration was found to be sufficient in all cases for $\mathrm{CO}_{2}$ formation to have ceased at each temperature. The $\mathrm{CO}_{2}$ emission (and in a later iteration also the $\mathrm{CO}$ emission) from each single-mineral sample was measured at the given temperature before heating the furnace to the next highest temperature and the introduction of a fresh sample. The weight of each sample was measured before and after heating. The carrier gas used was either $\mathrm{O}_{2}$ or $\mathrm{N}_{2}$ at the flow rate of $100 \mathrm{~mL} \mathrm{~min}{ }^{-1}$.

For the mine site project samples, thermal decomposition of each sample was carried out at 450 and $1000^{\circ} \mathrm{C}$ for $30 \mathrm{~min}$, using different sub-samples, in a $\mathrm{N}_{2}$ atmosphere at gas 
flow rate of $100 \mathrm{~mL} \mathrm{~min}^{-1}$. Thermal ANC is then calculated from the difference in the total of the $\mathrm{CO}$ and $\mathrm{CO}_{2}$ off-gas, measured using IR, at these two temperatures.

$\mathrm{C}_{\text {neut }}(\mathrm{wt} \%)$, the $\mathrm{C}$ associated with carbonate neutralisation is calculated using Equation (2).

$C_{\text {neut }}(w t \%)=\frac{100 \times\left(\left(\text { weight }(C) \text { emission at } 800 \text { or } 1000{ }^{\circ} \mathrm{C}\right)-\left(\text { weight }(C) \text { emission at } 400,450 \text { or } 500{ }^{\circ} \mathrm{C}\right)\right)}{\text { weight of sample prior to decomposition }}$

$\mathrm{ANC}_{\text {therm-carb }}$ is then calculated using Equation (3).

$$
\mathrm{ANC}_{\text {therm-carb }}=30.6 \times \mathrm{C}_{\text {neut }}(\mathrm{wt} \%) \times 32.065 / 12
$$

\section{Results}

\subsection{Single Minerals}

\subsubsection{Mineralogy and Bulk Assay}

The quantitative mineralogy for the selected 'single' carbonate minerals is given in Table 1. All these carbonate minerals were present in their respective samples at $>90 \mathrm{wt} \%$ except for magnesite and ankerite. The bulk assay for the single-carbonate minerals is provided in Supplementary Material (SM) Table S1.

\subsubsection{ANC by Titration-Methodology 1}

Table 2 provides the ANC values calculated from $\mathrm{Ca}, \mathrm{Mg}$ alone, and with $\mathrm{Na}$ and $\mathrm{K}$, and with $\mathrm{Na}, \mathrm{K}$, and $\mathrm{Mn}$, $\mathrm{ANC}$ derived from the total carbon assay $\left(\mathrm{ANC}_{\mathrm{IC}}\right.$, it is assumed that no organic $C$ is present) and ANC measured by titration methodology (1) $\left(\mathrm{ANC}_{\text {titrate-all }}\right)$. For these systems, the method of derivation of ANC using $\mathrm{Na}, \mathrm{K}, \mathrm{Ca}, \mathrm{Mg}$ and $\mathrm{Mn}$ is acceptable due to the lack of minerals, other than carbonates, likely to contain these elements (ANC due to $\mathrm{Na}$ and $\mathrm{K}$ is minor). It is noted that this method of derivation of ANC would likely not be realistic for more complicated real mineral assemblages where these elements may not be readily soluble. The rationale for the calculation of ANC based on these cations can be found in their Pourbaix diagrams [23]. On dissolution, these cations will remain unhydroxylated until high $\mathrm{pH}$. This ensures the ions provide acid-neutralising capacity irrespective of the ANC test $\mathrm{pH}$ regime.

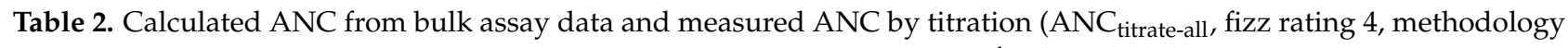
(1)) for single-mineral carbonate samples. Units for all ANC are $\mathrm{kg} \mathrm{H}_{2} \mathrm{SO}_{4} \mathrm{t}^{-1}$.

\begin{tabular}{|c|c|c|c|c|c|}
\hline & $\begin{array}{c}\mathrm{ANC}_{\mathrm{IC}} \\
\text { (LECO Total Carbon) }\end{array}$ & $\begin{array}{c}\text { ANC } \\
\text { (Ca, Mg Assay) }\end{array}$ & $\begin{array}{c}\text { ANC } \\
\text { (Ca, Mg, Na, K Assay) }\end{array}$ & $\begin{array}{c}\mathrm{ANC}_{\text {calc }} \\
\text { (Ca, } \mathrm{Mg}, \mathrm{Na}, \mathrm{K}, \mathrm{Mn} \text { Assay) }\end{array}$ & $\mathrm{ANC}_{\text {titrate-all }}$ \\
\hline Dolomite & 1070 & 1027 & 1045 & 1047 & 1027 \\
\hline Magnesite & 1168 & 1125 & 1127 & 1127 & 1140 \\
\hline Calcite & 923 & 993 & 994 & 994 & 989 \\
\hline Siderite & 907 & 144 & 144 & 144 & 175 \\
\hline Malachite & 346 & 1 & 2 & 2 & 212 \\
\hline Azurite & 433 & 3 & 3 & 3 & 207 \\
\hline Rhodochrosite & 915 & 81 & 81 & 853 & 811 \\
\hline Ankerite & 382 & 168 & 169 & 184 & 201 \\
\hline
\end{tabular}

$\mathrm{ANC}_{\text {titrate-all }}$ was similar to that calculated from total carbon or from the bulk solids assays for $\mathrm{Ca}, \mathrm{Mg}$, Na and $\mathrm{K}$ for calcite, dolomite and magnesite (Table 2). For siderite, the $\mathrm{ANC}_{\text {titrate-all }}$ was also similar to that calculated from the bulk assay of $\mathrm{Na}, \mathrm{K}, \mathrm{Mg}$ and $\mathrm{Ca}$ suggesting effective oxidation and precipitation of the iron component of the siderite, i.e., the dissolution of siderite did not provide neutralisation.

For malachite and azurite the ANC calculated from the bulk assay of $\mathrm{Ca}, \mathrm{Mg}, \mathrm{Na}$ and

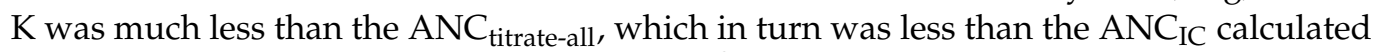
from total carbon. This suggests that some $\mathrm{Cu}^{2+}$ remained in solution despite titration to $\mathrm{pH}$ 7. The Pourbaix diagram [23] indicates this to be possible as aqueous $\mathrm{Cu}^{2+}$ is shown to be present at $\mathrm{pH} 7$ at Eh (SHE) $>200 \mathrm{mV}$, therefore being measured as neutralisation, although also likely to have the potential to generate NMD. The amount of $\mathrm{Cu}$ in the 
sample required to remain in solution as $\mathrm{Cu}^{2+}$ to achieve the measured average ANC for these phases is $13.4 \mathrm{wt} \%$ for azurite and $13.7 \mathrm{wt} \%$ for malachite, or $24 \%$ and $23 \%$ of the $\mathrm{Cu}$ present in the samples, respectively.

For rhodochrosite, the $\mathrm{ANC}_{\text {titrate-all }}$ was of similar magnitude to the $\mathrm{ANC}_{\mathrm{IC}}(811 \mathrm{cf}$. $915 \mathrm{~kg} \mathrm{H}_{2} \mathrm{SO}_{4} \mathrm{t}^{-1}$ ) but was much greater than the ANC calculated from the bulk assay of $\mathrm{Ca}, \mathrm{Mg}, \mathrm{Na}$ and $\mathrm{K}$. This suggests that much of the $\mathrm{Mn}$ has remained in solution and therefore constitutes neutralisation, although also likely to have the potential to generate NMD. Again, the Pourbaix diagram [23] suggests that this is reasonably the case with both high $\mathrm{pH}$ and Eh required for precipitation of $\mathrm{MnO}_{2(\mathrm{~s})}$. The amount of $\mathrm{Mn}$ in the sample required to remain in solution to achieve the measured ANC is $43.2 \mathrm{wt} \%$ or $93 \%$ of the $\mathrm{Mn}$ available in the rhodochrosite sample. $\mathrm{ANC}_{\text {calc }}$ calculated from $\mathrm{Ca}, \mathrm{Na}, \mathrm{K}, \mathrm{Mg}$ and $\mathrm{Mn}$ (Table 2) is $853 \mathrm{~kg} \mathrm{H}_{2} \mathrm{SO}_{4} \mathrm{t}^{-1}$ as compared to the measured $\mathrm{ANC}_{\text {titrate-all }}$ value of $811 \mathrm{~kg} \mathrm{H}_{2} \mathrm{SO}_{4} \mathrm{t}^{-1}$. The conclusion that rhodochrosite provides viable neutralisation from Mn agrees with the findings of [6], although the risks of NMD need to be acknowledged.

The ankerite sample was a more complicated system than the other samples as it contained more dolomite than ankerite and almost the same amount of siderite as ankerite (Table 1). Given the presence of siderite, and likely Fe in the ankerite, it is predictable that the $\mathrm{ANC}_{\mathrm{IC}}$ calculated from the total carbon assay (Table 2) is greater than the titrated $\mathrm{ANC}_{\text {titrate-all }}$ (382 cf. $201 \mathrm{~kg} \mathrm{H}_{2} \mathrm{SO}_{4} \mathrm{t}^{-1}$ ). The $\mathrm{ANC}_{\text {calc }}$ calculated from the bulk assays for $\mathrm{Ca}, \mathrm{Mg}, \mathrm{Na}, \mathrm{K}$ and $\mathrm{Mn}$ is in good agreement with the titrated $\mathrm{ANC}$ at $184 \mathrm{~kg} \mathrm{H}_{2} \mathrm{SO}_{4} \mathrm{t}^{-1}$.

\subsubsection{Thermal Decomposition}

The decomposition behaviours of these selected carbonate minerals were studied using gravimetric and IR analyses of the emitted gases in $\mathrm{O}_{2}$ or $\mathrm{N}_{2}$ environments.

Using $\mathrm{O}_{2}$ as the Carrier Gas

In Figure 1, the $\mathrm{CO}_{2}$ emissions across sequential temperature ranges are shown, i.e., $<400{ }^{\circ} \mathrm{C}, 400-500{ }^{\circ} \mathrm{C}$, etc. The data in Figure 1 are presented as Equation (4):

$100 \times\left(\Delta \mathrm{CO}_{2}\right.$ emission $) /\left(\right.$ total expected $\mathrm{CO}_{2}$ from the $\mathrm{LECO}$ total $\mathrm{C}$ measurement $)$

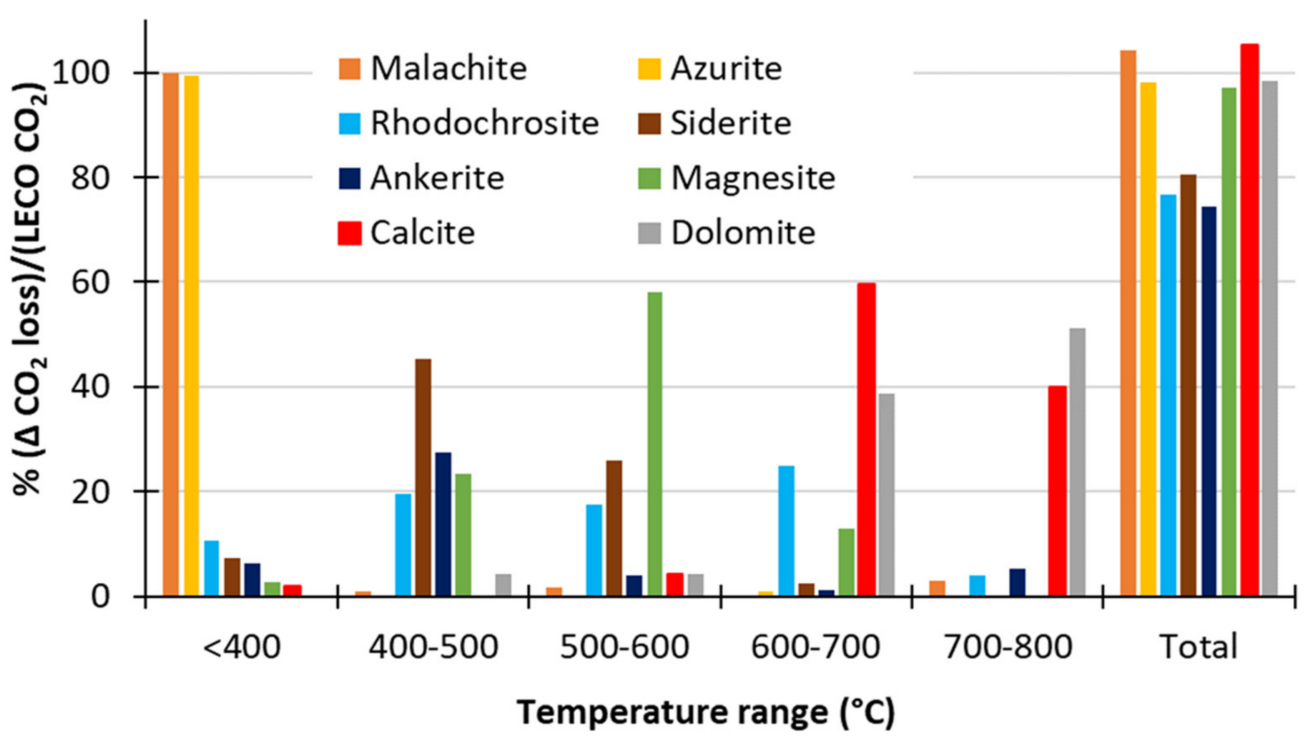

Figure 1. Percentage (\%) of expected $\mathrm{CO}_{2}$ emission as a function of temperature range using $\mathrm{O}_{2}$ as the carrier gas.

$\Delta \mathrm{CO}_{2}$ emission is, for instance, the $\mathrm{CO}_{2}$ emission measured at $500{ }^{\circ} \mathrm{C}$ minus that measured at $400{ }^{\circ} \mathrm{C}$. The data are normalised by the LECO total carbon measurement to assess whether the decomposition is complete. 
Calcite and dolomite decomposed at $>600{ }^{\circ} \mathrm{C}$ to also give approximately $100 \% \mathrm{CO}_{2}$ emission (Figure 1). Malachite and azurite also decomposed to give $100 \% \mathrm{CO}_{2}$ emission, at $<400{ }^{\circ} \mathrm{C}$. Magnesite progressively decomposes between 400 and $700{ }^{\circ} \mathrm{C}$ to give approximately $100 \%$ total $\mathrm{CO}_{2}$ emission.

Siderite and rhodochrosite were found to decompose at $>400{ }^{\circ} \mathrm{C}$ but with only approximately $80 \% \mathrm{CO}_{2}$ emission up to $800{ }^{\circ} \mathrm{C}$. Ankerite progressively decomposed from $500{ }^{\circ} \mathrm{C}$ upwards and even at $1000^{\circ} \mathrm{C}$ (note data between 800 and $1000{ }^{\circ} \mathrm{C}$ are not shown in Figure 1) only gave rise to approximately $80 \% \mathrm{CO}_{2}$ emission (Figure 1). Remnant $\mathrm{C}$ in the residues were all found to be less $<1 \mathrm{wt} \%$ and measurement of $\mathrm{CO}$ emission (also using IR) for siderite at $700{ }^{\circ} \mathrm{C}$ was found to equate to $0.68 \mathrm{wt} \% \mathrm{C}$. This, therefore, does not explain the 'missing' $\mathrm{CO}_{2}$ emission for siderite of approximately $20 \%$. As the 'missing $\mathrm{C}^{\prime}$ is neither in the emitted gases as $\mathrm{CO}$ or in the solids the most likely explanation is that the initial measurement of LECO total $\mathrm{C}$ was too high. The total $\mathrm{CO}_{2}$ emissions would suggest carbon concentrations of $3.8,8.6$ and $8.3 \mathrm{wt} \% \mathrm{C}$ for ankerite, siderite and rhodochrosite as compared to the assay values of $4.7,11.1$ and $11.2 \mathrm{wt} \% \mathrm{C}$, respectively.

Magnesite, dolomite and calcite show approximately $100 \%$ total weight loss as compared to the expected weight loss based on the $\mathrm{CO}_{2}$ emission (Table 3) assuming decomposition to $\mathrm{CaO}$ and/or $\mathrm{MgO}$ and emission of $\mathrm{CO}_{2}$. The weight losses for siderite, ankerite and rhodochrosite are also close to $100 \%$ of those calculated based on the total $\mathrm{CO}_{2}$ emission (Table 3) assuming decomposition to $\mathrm{FeO}$ and $\mathrm{MnO}$ for siderite and rhodochrosite, respectively, and based on stoichiometric Equation (5) for ankerite.

$$
\mathrm{Ca}(\mathrm{Mg}, \mathrm{Fe}, \mathrm{Mn})\left(\mathrm{CO}_{3}\right)_{2(\mathrm{~s})} \rightarrow \mathrm{CaO}_{(\mathrm{s})}+\frac{1}{3} \mathrm{MgO}_{(\mathrm{s})}+\frac{1}{3} \mathrm{FeO}_{(\mathrm{s})}+\frac{1}{3} \mathrm{MnO}_{(\mathrm{s})}+2 \mathrm{CO}_{2(\mathrm{~g})}
$$

Table 3. Measured weight loss and weight loss calculated from the $\mathrm{CO}_{2}$ emissions (wt $\%$ ) for singlemineral carbonates. Meas-measured; Calc-calculated.

\begin{tabular}{|c|c|c|c|c|c|c|c|c|}
\hline \multirow{2}{*}{$\begin{array}{c}\text { Temperature } \\
\left({ }^{\circ} \mathrm{C}\right)\end{array}$} & \multicolumn{2}{|c|}{ Magnesite } & \multicolumn{2}{|c|}{ Dolomite } & \multicolumn{2}{|c|}{ Calcite } & \multicolumn{2}{|c|}{ Siderite } \\
\hline & Meas & Calc & Meas & Calc & Meas & Calc & Meas & Calc \\
\hline 400 & 1 & 1 & 0 & 0 & 1 & 1 & 3 & 3 \\
\hline 500 & 14 & 14 & 2 & 2 & 1 & 1 & 21 & 21 \\
\hline 600 & 44 & 44 & 4 & 4 & 2 & 2 & 32 & 32 \\
\hline 700 & 51 & 51 & 23 & 23 & 27 & 27 & 33 & 33 \\
\hline 800 & 51 & 51 & 47 & 47 & 44 & 44 & 33 & 33 \\
\hline \multirow{2}{*}{$\begin{array}{c}\text { Temperature } \\
\left({ }^{\circ} \mathrm{C}\right)\end{array}$} & \multicolumn{2}{|c|}{ Ankerite } & \multicolumn{2}{|c|}{ Rhodochrosite } & \multicolumn{2}{|c|}{ Azurite } & \multicolumn{2}{|c|}{ Malachite } \\
\hline & Meas & Calc & Meas & Calc & Meas & Calc & Meas & Calc \\
\hline 400 & 1 & 1 & 4 & 4 & 31 & 23 & 28 & 22 \\
\hline 500 & 6 & 6 & 12 & 12 & 30 & 23 & 28 & 22 \\
\hline 600 & 7 & 7 & 20 & 20 & 31 & 23 & 28 & 22 \\
\hline 700 & 7 & 7 & 30 & 30 & 30 & 23 & 28 & 22 \\
\hline 800 & 8 & 8 & 31 & 32 & 30 & 23 & 29 & 23 \\
\hline
\end{tabular}

However, it can be seen from Table 3 that malachite and azurite give rise to greater than expected weight loss based on measured $\mathrm{CO}_{2}$, assuming $\mathrm{H}_{2} \mathrm{O}$ and $\mathrm{CO}_{2}$ emissions and decomposition to $\mathrm{CuO}$. However, the total carbon values of $5.3 \mathrm{wt} \%$ for azurite and $4.2 \mathrm{wt} \%$ for malachite are less than suggested by quantitative XRD (6.9 wt $\%$ and $5.4 \mathrm{wt} \%$, respectively) or by the $\mathrm{Cu}$ assay $(7.0 \mathrm{wt} \%$ and $5.6 \mathrm{wt} \%)$. If the expected weight loss, assuming $100 \% \mathrm{CO}_{2}$ emission, is calculated using the quantitative XRD derived carbon concentrations, then the calculated weight loss would be $30.5 \mathrm{wt} \%$ for azurite and $28.0 \mathrm{wt} \%$ for malachite, both very close to the measured weight loss.

It is clear from Figure 1 that there exists good separation of malachite, azurite $\left(<400{ }^{\circ} \mathrm{C}\right)$ and siderite $\left(400-600^{\circ} \mathrm{C}\right)$ from calcite and dolomite. However, there is not good separation of siderite from either rhodochrosite or magnesite. 'Ankerite' is not directly interpretable 
due to it being mixed phase. Although these $\mathrm{Cu}$-containing carbonate minerals (azurite

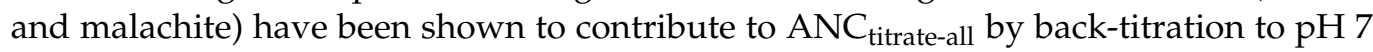
(Section 3.1.2) it was considered desirable to discriminate against these minerals during thermal decomposition determination of $\mathrm{ANC}_{\text {therm-carb }}$.

To attempt to deconvolute the decomposition temperatures of siderite and magnesite, further measurements using the same conditions were undertaken at 450 and $550{ }^{\circ} \mathrm{C}$. Nevertheless, there was still no clear temperature demarcation of the decomposition of siderite and magnesite using $\mathrm{O}_{2}$ as the carrier gas. The best temperature, as for the measurements shown in Figure 1 , remained $500{ }^{\circ} \mathrm{C}$ with $26.8 \%$ and $64.9 \%$ of the $\mathrm{CO}_{2}$ emission from magnesite and siderite occurring below this temperature. This would not provide adequate deconvolution of these carbonate minerals.

Using $\mathrm{N}_{2}$ as the Carrier Gas

Comparison of thermal measurements of carbonate minerals undertaken in air [11] and in $\mathrm{N}_{2}$ [19] have indicated that the temperature of decomposition of siderite is significantly decreased in $\mathrm{N}_{2}$, as compared to air, whereas the temperature of decomposition of magnesite is much less affected. The decomposition temperatures of calcite and dolomite, while significantly decreased, remain above that for magnesite.

Following from these observations the $\mathrm{CO}_{2}$ (and $\mathrm{CO}$ ) emissions from rhodochrosite, magnesite and siderite were analysed at 400, 450, 500, 550, 600, 700 and $800{ }^{\circ} \mathrm{C}$ using $\mathrm{N}_{2}$ as the carrier gas (decomposition duration $30 \mathrm{~min}, 100 \mathrm{~mL} \mathrm{~min}^{-1}$ gas flow rate; Figure 2). Magnesite shows little change. The decomposition of rhodochrosite at $600-700{ }^{\circ} \mathrm{C}$ is smaller in $\mathrm{N}_{2}$ carrier gas as compared to $\mathrm{O}_{2}$ carrier gas. The decomposition temperature of siderite is significantly reduced in $\mathrm{N}_{2}$ carrier gas, as compared to $\mathrm{O}_{2}$ carrier gas, with negligible decomposition at $>500{ }^{\circ} \mathrm{C}$.

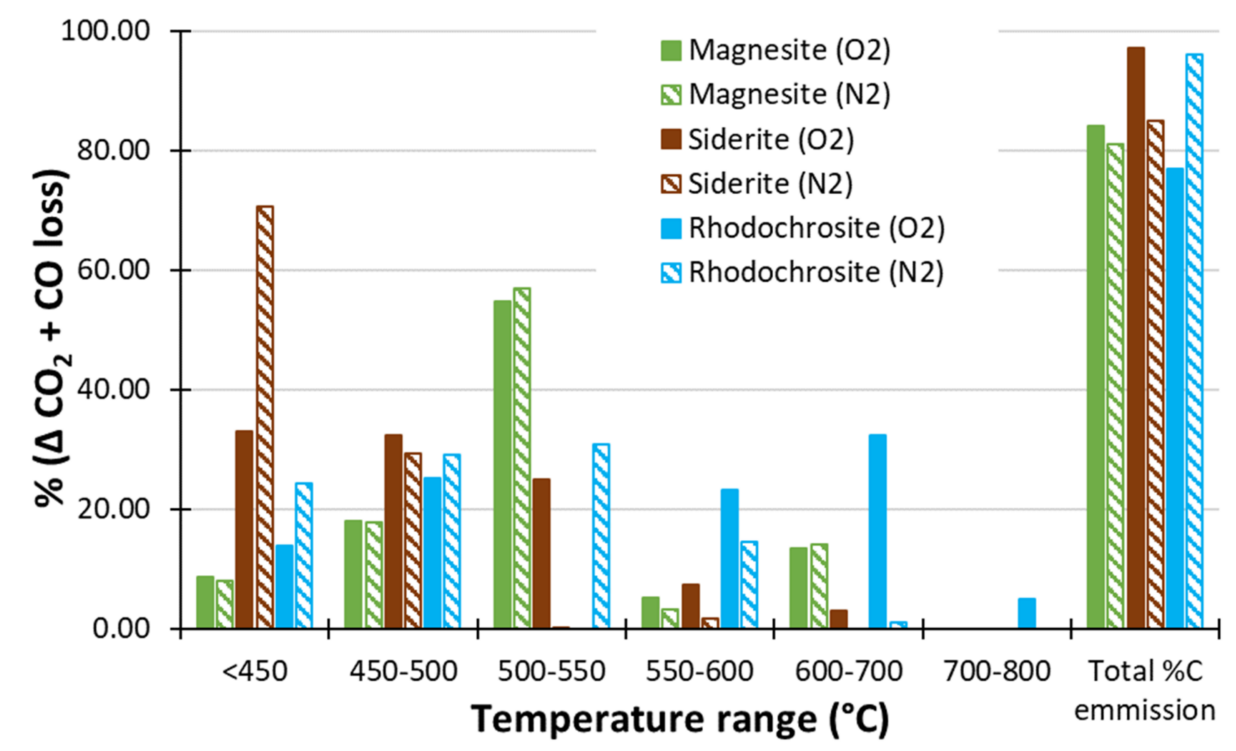

Figure 2. Decomposition behaviours of magnesite, rhodochrosite and siderite using $\mathrm{N}_{2}$ and $\mathrm{O}_{2}$ carrier gases. To show rhodochrosite on this graph, the data for $<400{ }^{\circ} \mathrm{C}$ are shown as $<450{ }^{\circ} \mathrm{C}$, and the data for $500-600{ }^{\circ} \mathrm{C}$ are shown as $550-600{ }^{\circ} \mathrm{C}$. The sum of the values for each mineral across the temperature ranges has been normalised to $100 \%$. The total $\% \mathrm{C}$ emission, as a $\%$ of the total C present, is also provided.

The emissions of $\mathrm{C}$, as a percentage of total LECO carbon, in $\mathrm{N}_{2}$ carrier gas as compared to $\mathrm{O}_{2}$ carrier gas increased for rhodochrosite and siderite (77 to $84 \%$; 81 to $85 \%$ ) but remained unchanged for magnesite (97 to 96\%). The agreement (Table 4) between measured weight loss and calculated weight loss using Equations (6)-(8) is good. (Note: the full 
weight loss and \% $\mathrm{CO}$ and $\mathrm{CO}_{2}$ emission values for the single-carbonate mineral samples with both $\mathrm{O}_{2}$ and $\mathrm{N}_{2}$ carrier gas are provided in SM Tables S2-S4.)

Table 4. Measured weight loss and weight loss calculated from the total of $\mathrm{CO}_{2}$ and $\mathrm{CO}$ emissions $\left(\mathrm{wt} \%\right.$ ) for rhodochrosite, magnesite and siderite in $\mathrm{N}_{2}$ carrier gas. Meas-measured; Calc—calculated.

\begin{tabular}{ccccccc}
\hline \multirow{2}{*}{ Temperature $\left({ }^{\circ} \mathbf{C}\right)$} & \multicolumn{2}{c}{ Rhodochrosite } & \multicolumn{2}{c}{ Magnesite } & \multicolumn{2}{c}{ Siderite } \\
\cline { 2 - 7 } & Meas & Calc & Meas & Calc & Meas & Calc \\
\hline 450 & 8 & 7 & 3.3 & 3 & 24 & 23 \\
500 & 17 & 18 & 12 & 12 & 34 & 32 \\
550 & 27 & 28 & 43 & 40 & 35 & 32 \\
600 & 34 & 34 & 44 & 43 & 35 & 32 \\
700 & 35 & 34 & 50 & 50 & 36 & 34 \\
\hline
\end{tabular}

Rhodochrosite

$$
\begin{aligned}
\mathrm{MnCO}_{3(\mathrm{~s})} & \rightarrow \mathrm{MnO}_{(\mathrm{s})}+\mathrm{CO}_{2(\mathrm{~g})} \\
\mathrm{MnCO}_{3(\mathrm{~s})} & \rightarrow \mathrm{MnO}_{(\mathrm{s})}+\mathrm{CO}_{(\mathrm{g})}+\frac{1}{2} \mathrm{O}_{2(\mathrm{~g})}
\end{aligned}
$$

Magnesite

$$
\begin{aligned}
& \mathrm{MgCO}_{3(\mathrm{~s})} \rightarrow \mathrm{MgO}_{(\mathrm{s})}+\mathrm{CO}_{2(\mathrm{~g})} \\
& \mathrm{MgCO}_{3(\mathrm{~s})} \rightarrow \mathrm{MgO}_{(\mathrm{s})}+\mathrm{CO}_{(\mathrm{g})}+\frac{1}{2} \mathrm{O}_{2(\mathrm{~g})}
\end{aligned}
$$

Siderite

$$
\begin{aligned}
\mathrm{FeCO}_{3(\mathrm{~s})} & \rightarrow \mathrm{FeO}_{(\mathrm{s})}+\mathrm{CO}_{2(\mathrm{~g})} \\
\mathrm{FeCO}_{3(\mathrm{~s})} & \rightarrow \mathrm{Feg}+\mathrm{CO}_{(\mathrm{g})}+\frac{1}{2} \mathrm{O}_{2(\mathrm{~g})}
\end{aligned}
$$

\subsubsection{Thermal Decomposition ANC of Single-Carbonate Minerals}

Figure 3 shows a comparison of the single-mineral carbonate $\mathrm{ANC}_{\text {therm-carb }}$ values derived from thermal decomposition as compared to the titrated $\mathrm{ANC}_{\text {titrate-all }}$ (ANC methodology (1), Section 3.1.2). It is clear from this graph that the best correlation to titrated $\mathrm{ANC}_{\text {titrate-all }}$ is when the decomposition behaviour in $\mathrm{N}_{2}$ at $450{ }^{\circ} \mathrm{C}$ is used for magnesite, siderite and rhodochrosite. The decomposition behaviour of dolomite, calcite, azurite, and malachite were not examined in $\mathrm{N}_{2}$. However, it is unlikely that the behaviours of these phases would change sufficiently significantly in $\mathrm{N}_{2}$ carrier gas, as opposed to $\mathrm{O}_{2}$, to make the application of $450{ }^{\circ} \mathrm{C}$ invalid. Were this to be the case an increase from $<400{ }^{\circ} \mathrm{C}$ decomposition temperature for azurite and malachite and decreases in decomposition temperatures for calcite and dolomite from $>600{ }^{\circ} \mathrm{C}$ would have to occur on change from the carrier gas from $\mathrm{O}_{2}$ to $\mathrm{N}_{2}$. Ankerite was not examined in $\mathrm{N}_{2}$ carrier gas due to the mixed-phase nature of this sample.

The correlation of $\mathrm{ANC}_{\text {therm-carb }}$ (using the decomposition at $450{ }^{\circ} \mathrm{C}$ where available, otherwise $400^{\circ} \mathrm{C}$ ) to the $\mathrm{ANC}_{\text {titrate-all }}$ is shown in Figure 4a. The slope of the line of best fit is close to 1 with correlation coefficient of 0.94 . The line of best fit results in smaller values than those measured (i.e., $y$-axis intercept of -108) due primarily to the very low $\mathrm{ANC}_{\text {therm-carb }}$ values for rhodochrosite, malachite and azurite. Figure $4 \mathrm{~b}$ shows the correlation of the $\mathrm{ANC}_{\text {calc }}$ calculated using the bulk assay concentrations of $\mathrm{Mg}, \mathrm{Na}, \mathrm{K}, \mathrm{Ca}$, and $\mathrm{Mn}$ (Table 2) with $\mathrm{ANC}_{\text {therm-carb. }}$. The correlation coefficient is 0.96 with slope of 0.89 and intercept near zero providing confidence in the method of distinguishing neutralising (ANC) from non-neutralising carbonates. 


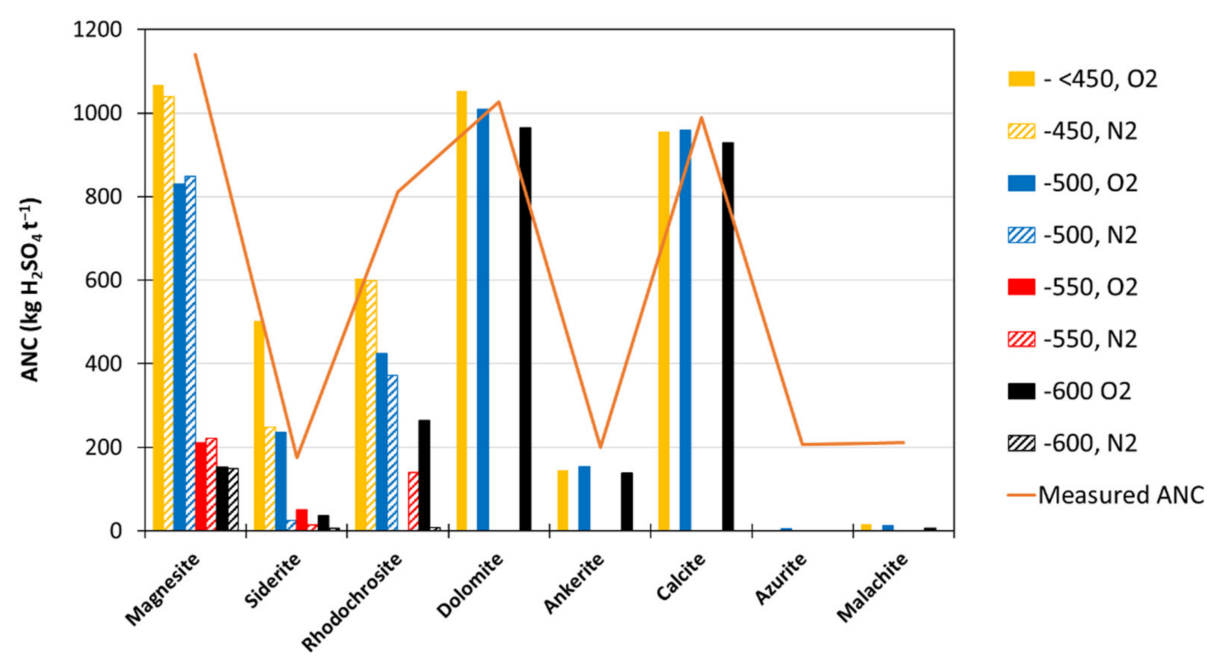

Figure 3. Comparison of $\mathrm{ANC}$ derived from thermal decomposition data $\left(\mathrm{ANC}_{\text {thermal-carb }}\right)$ and titration $\left(\mathrm{ANC}_{\text {titrate-all }}\right)$. The numbers in the legend refer to the temperature below which the $\mathrm{CO}_{2}$ emission was considered to be associated with non-neutralising carbonate phases. Note: The ' $<450, \mathrm{O}_{2}$ ' data are derived from the $400{ }^{\circ} \mathrm{C}, \mathrm{O}_{2}$ carrier gas values for dolomite, ankerite, calcite, azurite and malachite.

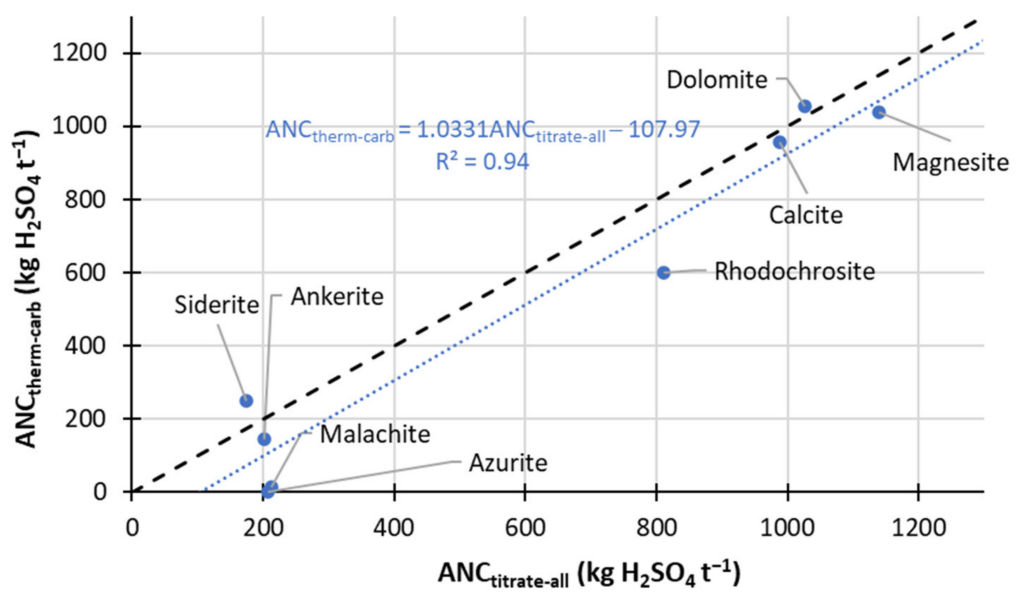

(a)

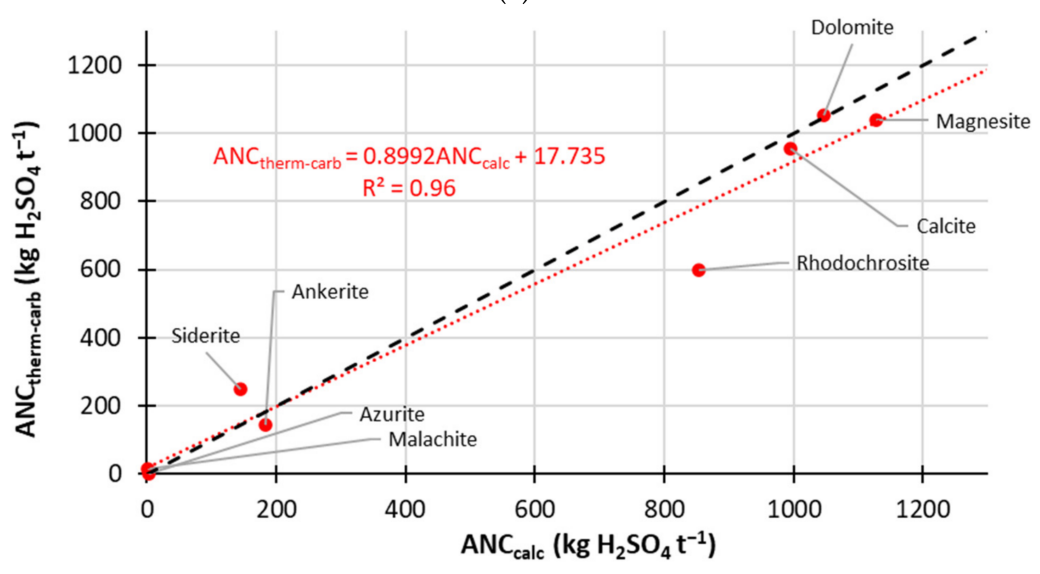

(b)

Figure 4. (a) Correlation of $\mathrm{ANC}_{\text {therm-carb }}$ and $\mathrm{ANC}_{\text {titrate-all }}$ (ANC methodology (1)). (b) Correlation of $\mathrm{ANC}_{\text {therm-carb- }}$ and $\mathrm{ANC}_{\text {calc }}$ calculated from bulk assay concentrations for $\mathrm{Mg}, \mathrm{K}, \mathrm{Na}, \mathrm{Ca}$, and $\mathrm{Mn}$. The dark dotted line indicates the ratio of 1:1. 


\subsection{Mine Site Project Waste Rock Samples}

Twenty samples were chosen for analysis based on:

(1) Samples with the greatest difference between $\mathrm{ANC}_{\text {titrate-carb }}$ and $\mathrm{ANC}_{\mathrm{IC}}$ were chosen as these were likely to provide the most information on what is contributing to the $\mathrm{ANC}$ values. When $\mathrm{ANC}_{\text {titrate-carb }}$ minus $\mathrm{ANC}_{\mathrm{IC}}$ is positive it may be due to noncarbonate neutralisation and when this value is negative it may be due to the presence of siderite.

(2) Samples that were categorised as uncertain where chosen, i.e., either NAG $\mathrm{pH}<4.5$ and NAPP $<0$, or NAG pH $>4.5$ and NAPP $>0$ (for a description of the net acid generation, NAG, test refer to [4]).

(3) Samples with either low or high $\mathrm{NAG} \mathrm{pH}$ with little difference between $\mathrm{ANC}_{\text {titrate-carb }}$ and $\mathrm{ANC}_{\mathrm{IC}}$ were not chosen.

The MLA-derived carbonate mineralogy relevant to ANC determination for the 20 mine site samples examined is given in Table 5. In Table 5 the ANC values calculated from total carbon $\left(\mathrm{ANC}_{\mathrm{IC}}-\right.$ it is assumed that no organic carbon is present; $\mathrm{C}$ is present at $<1.5 \mathrm{wt} \%$ except for three samples) and measured using ANC titration by methodology (2) $\left(\mathrm{ANC}_{\text {titrate-carb }}\right)$ are compared. For the samples containing elevated siderite and no other detected carbonate minerals (samples $12-20$ ) the $\mathrm{ANC}_{\text {titrate-carb }}$ is very small indicating that siderite is effectively excluded. The ratio of $\mathrm{ANC}_{\text {titrate-carb }}$ to $\mathrm{ANC}_{\mathrm{IC}}$ for the other samples is close to $1(0.8-1.2)$ except for sample 3. This sample was found to contain $30.7 \mathrm{wt} \%$ $\mathrm{Mg}$-clay by MLA. It is likely that a portion of the $\mathrm{Mg}$-based neutralisation from this clay contributed to the $\mathrm{ANC}_{\text {titrate-carb }}$ of $118 \mathrm{~kg} \mathrm{H}_{2} \mathrm{SO}_{4} \mathrm{t}^{-1}$ ( $c f .85 \mathrm{~kg} \mathrm{H}_{2} \mathrm{SO}_{4} \mathrm{t}^{-1} \mathrm{ANC}_{\mathrm{IC}}$ ).

Table 5. Quantitative MLA mineral composition analysis (wt $\%$ ) of the 20 mine site samples. Total carbon assays have been used to calculate $\mathrm{ANC}_{\mathrm{IC}}$ (note: it is assumed that there is no organic $\mathrm{C}$ ). $\mathrm{ANC}_{\text {titrate-carb }}$ (titration methodology (2)) values are also provided. All ANC values are in units of $\mathrm{kg} \mathrm{H}_{2} \mathrm{SO}_{4} \mathrm{t}^{-1}$. NA-not available. Where a specific mineral (ankerite, calcite or dolomite) was not identified as being present the cell has been left empty.

\begin{tabular}{|c|c|c|c|c|c|c|c|c|}
\hline Sample \# & $\begin{array}{c}\text { Ankerite } \\
(w t \%)\end{array}$ & $\begin{array}{l}\text { Calcite } \\
(w t \%)\end{array}$ & $\begin{array}{c}\text { Dolomite } \\
\text { (wt } \%)\end{array}$ & $\begin{array}{c}\text { Siderite } \\
\text { (wt } \%)\end{array}$ & $\begin{array}{c}\text { Total C } \\
(\mathbf{w t} \%)\end{array}$ & $\mathrm{ANC}_{\mathrm{IC}}$ & $\mathrm{ANC}_{\text {titrate-carb }}$ & $\mathrm{ANC}_{\text {titrate-carb }} / \mathrm{ANC}_{\mathrm{IC}}$ \\
\hline 1 & 0.1 & 0.2 & 0.1 & & 0.08 & 7 & 8 & 1.2 \\
\hline 2 & & & & 1.3 & 0.24 & 20 & 16 & 0.8 \\
\hline 3 & & 5.8 & & 1.4 & 1.04 & 85 & 118 & 1.4 \\
\hline 4 & 4.5 & 0.9 & 4.6 & & 1.26 & 103 & 100 & 1.0 \\
\hline 5 & 2.2 & & 1.7 & & 0.64 & 52 & 60 & 1.1 \\
\hline 6 & 2.7 & & 8.5 & & 1.62 & 132 & 138 & 1.0 \\
\hline 7 & 1.3 & 1.2 & 2.6 & 0.1 & 0.70 & 57 & NA & NA \\
\hline 8 & 1.6 & & 2.9 & 0.1 & 0.78 & 64 & NA & NA \\
\hline 9 & 3.1 & & 12.7 & & 2.36 & 193 & 170 & 0.9 \\
\hline 10 & 5.9 & & 3.4 & & 1.28 & 105 & 99 & 0.9 \\
\hline 11 & 6.3 & 1.5 & 7.2 & & 2.14 & 175 & 148 & 0.8 \\
\hline 12 & & & & 1.5 & 0.24 & 20 & 12 & 0.6 \\
\hline 13 & & & & 2.1 & 0.28 & 23 & 12 & 0.5 \\
\hline 14 & & & & 4.0 & 0.44 & 36 & 11 & 0.3 \\
\hline 15 & & & & 8.6 & 1.06 & 87 & 16 & 0.2 \\
\hline 16 & & & & 4.6 & 0.60 & 49 & 8 & 0.2 \\
\hline 17 & & & & 2.8 & 0.48 & 39 & 9 & 0.2 \\
\hline 18 & & & & 2.1 & 0.34 & 28 & 8 & 0.3 \\
\hline 19 & & & & 1.6 & 0.26 & 21 & 3 & 0.1 \\
\hline 20 & & & & 2.3 & 0.34 & 28 & 11 & 0.4 \\
\hline
\end{tabular}

The thermal decomposition data for the mine project samples are provided in Table 6. The $\%$ recovery of $\mathrm{CO}+\mathrm{CO}_{2}$ for sample 15 at $450{ }^{\circ} \mathrm{C}$ was smaller than expected, being only $46 \%$, given that this sample contained the greatest concentration of siderite at $8.6 \mathrm{wt} \%$. For this reason, the decomposition was repeated at $500{ }^{\circ} \mathrm{C}$, returning $83 \%$ emission of the expected $\mathrm{CO}+\mathrm{CO}_{2}$. It is these data that are included in the correlation given in Figure 5 .

Comparison of the $\mathrm{ANC}_{\text {therm-carb }}$ and $\mathrm{ANC}_{\text {titrate-carb }}$ (methodology (2) $\mathrm{ANC}$ ) values is given in Figure 5 for the 18 samples for which $\mathrm{ANC}_{\text {titrate-carb }}$ values are available. The correlation is excellent given the uncertainties involved in both approaches to carbonate 
ANC measurement. Moreover, the $x$-intercept is small (-3.5) suggesting the absence of systematic (i.e., constant) errors.

Table 6. Thermal decomposition $\mathrm{CO}$ and $\mathrm{CO}_{2}$ data for the mine project samples and $\mathrm{ANC}_{\text {therm-carb }}$.

\begin{tabular}{|c|c|c|c|c|c|c|c|}
\hline \multirow[b]{2}{*}{ Sample \# } & \multicolumn{3}{|c|}{$450^{\circ} \mathrm{C}$} & \multicolumn{3}{|c|}{$1000^{\circ} \mathrm{C}$} & \multirow[b]{2}{*}{$\begin{array}{l}\mathrm{ANC}_{\text {therm-carb }} \\
\left(\mathrm{kg} \mathrm{H}_{2} \mathrm{SO}_{4} \mathrm{t}^{-1}\right)\end{array}$} \\
\hline & $\begin{array}{c}\text { Generated } \\
\text { CO (\% of } \\
\text { Possible } \\
\text { Total })\end{array}$ & $\begin{array}{c}\text { Generated } \\
\mathrm{CO}_{2}(\% \text { of } \\
\text { Possible } \\
\text { Total })\end{array}$ & $\begin{array}{c}\mathrm{CO}+\mathrm{CO}_{2}(\% \\
\text { as } \mathrm{CO}_{2} \\
\text { Combined, of } \\
\text { Possible Total })\end{array}$ & $\begin{array}{c}\text { Generated } \\
\text { CO (\% of } \\
\text { Possible } \\
\text { Total) }\end{array}$ & $\begin{array}{c}\text { Generated } \\
\mathrm{CO}_{2}(\% \text { of } \\
\text { Possible } \\
\text { Total })\end{array}$ & $\begin{array}{l}\mathrm{CO}+\mathrm{CO}_{2}(\% \\
\text { as } \mathrm{CO}_{2} \\
\text { Combined, of } \\
\text { Possible Total })\end{array}$ & \\
\hline 1 & 5.6 & 61 & 70 & 0.0 & 93 & 93 & 2 \\
\hline 2 & 2.2 & 69 & 72 & 0.0 & 96 & 96 & 5 \\
\hline 3 & 0.3 & 17 & 17 & 0.1 & 97 & 97 & 68 \\
\hline 4 & 0.4 & 8.5 & 9.2 & 0.0 & 91 & 91 & 84 \\
\hline 5 & 0.7 & 11 & 12 & 0.1 & 102 & 102 & 47 \\
\hline 6 & 0.5 & 14 & 15 & 0.6 & 90 & 91 & 101 \\
\hline 7 & 0.8 & 13 & 14 & 0.0 & 95 & 95 & 46 \\
\hline 8 & 0.5 & 14 & 15 & 0.0 & 96 & 96 & 52 \\
\hline 9 & 0.4 & 9.2 & 10 & 1.5 & 83 & 86 & 147 \\
\hline 10 & 0.2 & 10 & 10 & 0.5 & 97 & 98 & 92 \\
\hline 11 & 0.1 & 6.5 & 6.7 & 0.00 & 89 & 89 & 144 \\
\hline 12 & 1.2 & 75 & 77 & 0.5 & 99 & 100 & 5 \\
\hline 13 & 0.6 & 60 & 61 & 0.5 & 98 & 98 & 8 \\
\hline 14 & 1.4 & 89 & 92 & 0.0 & 97 & 97 & 2 \\
\hline 15 & 0.7 & 45 & 46 & 0.5 & 97 & 98 & 45 \\
\hline 15 * & 0.4 & 82 & 83 & 0.5 & 97 & 98 & 13 \\
\hline 16 & 2.7 & 82 & 87 & 0.0 & 101 & 101 & 7 \\
\hline 17 & 1.9 & 88 & 91 & 0.0 & 97 & 97 & 2 \\
\hline 18 & 2.0 & 90 & 94 & 0.2 & 108 & 108 & 4 \\
\hline 19 & 3.5 & 75 & 81 & 1.5 & 98 & 100 & 4 \\
\hline 20 & 1.9 & 63 & 66 & 1.4 & 98 & 100 & 9 \\
\hline
\end{tabular}

* Sample 15 , decomposition measured at $500{ }^{\circ} \mathrm{C}$.

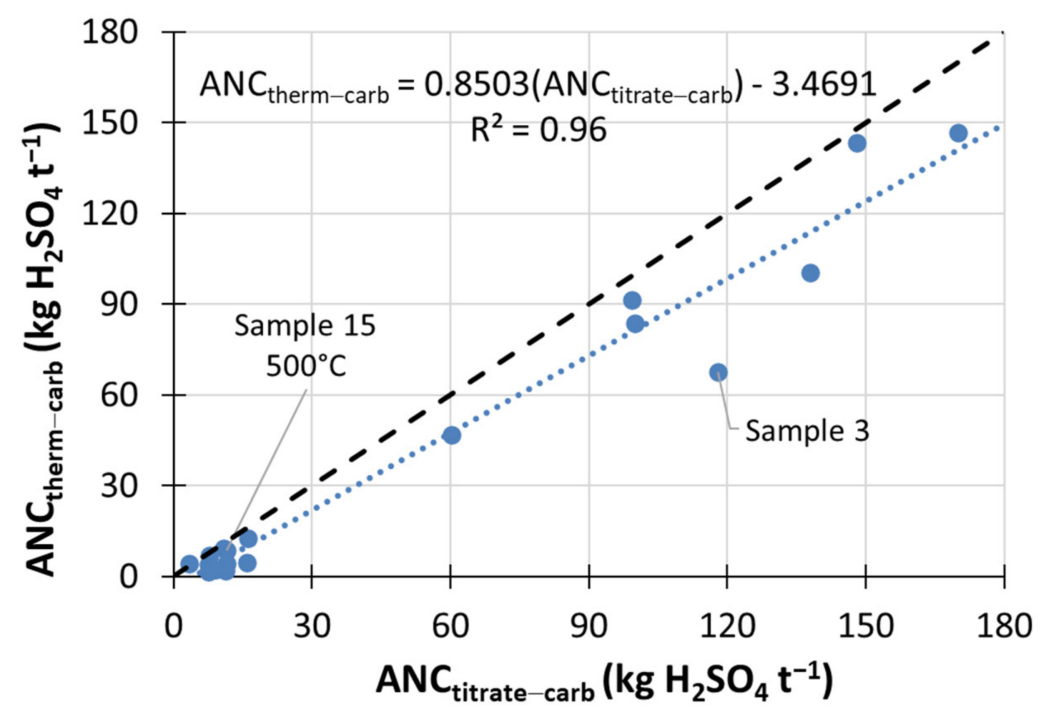

Figure 5. Correlation of $\mathrm{ANC}_{\text {therm-carb }}$ (using decomposition data at $450{ }^{\circ} \mathrm{C}$ except for sample 15 for which decomposition data at $500{ }^{\circ} \mathrm{C}$ was used) with the $\mathrm{ANC}_{\text {titrate-carb }}$ values. The dark dotted line indicates the ratio of $1: 1$ (note that $\mathrm{R}^{2}$ for this line $=0.86$ ). For sample 3 the greater $A N C_{\text {titrate-carb }}$ than $\mathrm{ANC}_{\text {therm-carb }}$ value is likely due to the partial inclusion of neutralisation from $\mathrm{Mg}$-clay in the $\mathrm{ANC}_{\text {titrate-carb }}$ value.

\section{Conclusions}

The purpose of this study was to develop an industry-applicable operational methodology for identification and quantification of different carbonate minerals for improved carbonate acid neutralisation capacity (ANC) determination for waste rock, tailings, and other mined materials. In this study, we have sought to adapt the method given in [20] to 
develop a method for carbonate ANC determination avoiding the issues of slow-reacting carbonates and non-neutralising carbonates.

The conclusions from measurement of the thermal decomposition behaviour of singlemineral carbonate samples are:

- Thermal decomposition of single-mineral carbonates in $\mathrm{O}_{2}$ carrier gas was found to give good separation of the decomposition of malachite and azurite $\left(<400{ }^{\circ} \mathrm{C}\right.$, considered to be non-neutralising for the purposes of these analyses) and siderite $\left(<600{ }^{\circ} \mathrm{C}\right)$ from calcite and dolomite $\left(>600^{\circ} \mathrm{C}\right)$.

- It was not possible to separate the decomposition events of siderite from rhodochrosite and magnesite in $\mathrm{O}_{2}$ carrier gas $\left(400-600^{\circ} \mathrm{C}\right)$.

- Thermal decomposition of single-mineral carbonates in $\mathrm{N}_{2}$ carrier gas depressed the thermal decomposition temperature of siderite $\left(70 \%\right.$ decomposition at $\left.<450{ }^{\circ} \mathrm{C}\right)$ enabling improved differentiation of siderite from rhodochrosite and magnesite.

- C emission due to 'neutralising' carbonates was calculated by subtracting carbon emission at $450{ }^{\circ} \mathrm{C}$ where available, otherwise $400{ }^{\circ} \mathrm{C}$, from the carbon emission at the greatest temperature applied ( 800 or $1000^{\circ} \mathrm{C}$ ). Data collected using $\mathrm{N}_{2}$ as the carrier gas were used if available. Thermal $\mathrm{ANC}\left(\mathrm{ANC}_{\text {therm-carb }}\right)$ was thereafter calculated as $30.6 \times \mathrm{C} \mathrm{wt} \% \times 32.065 / 12$.

- Correlation of $\mathrm{ANC}_{\text {carb }}$ to calculated $\mathrm{ANC}$ (using $\mathrm{Mg}, \mathrm{K}, \mathrm{Na}, \mathrm{Ca}$ and $\mathrm{Mn}$ ) gave rise to the line of best fit of:

$$
\mathrm{ANC}_{\text {therm-carb }}=\left(0.8992 \times \mathrm{ANC}_{\text {calc }}\right)+17.735
$$

with $R^{2}$ of 0.96 .

- Based on this outcome the conditions of thermal decompositions for each sample at 450 and $1000{ }^{\circ} \mathrm{C}$ for $30 \mathrm{~min}$ in $\mathrm{N}_{2}$ carrier gas at flow rate of $100 \mathrm{~mL} \mathrm{~min}{ }^{-1}$ were defined for examination of mine project waste rock samples.

The conclusions from analysis of 20 real mine samples are:

- $\quad \mathrm{ANC}_{\text {therm-carb }}$ determination using decomposition measurements at $4500^{\circ} \mathrm{C}$ (and $500{ }^{\circ} \mathrm{C}$ for one high siderite sample) and $1000{ }^{\circ} \mathrm{C}$ in $\mathrm{N}_{2}$ carrier gas (flow rate $100 \mathrm{~mL} \mathrm{~min}{ }^{-1}$ ) gave excellent correlation to the titration $\mathrm{ANC}_{\text {titrate-carb }}$ (available for 18 samples, methodology (2)) values (that focused on carbonate ANC):

$$
\mathrm{ANC}_{\text {therm-carb }}=\left(0.85 \times \mathrm{ANC}_{\text {titrate-carb }}\right)-3.4691\left(\mathrm{R}^{2}=0.96\right)
$$

- This correlation is valid for samples containing both non-neutralising carbonates and sources of neutralisation arising from silicates and ion exchange.

For the project waste rock samples studied, this methodology for determination of acid neutralisation capacity from carbonate minerals has the potential, with laboratory development, to be reliable and cost-effective. Moreover, using this methodology there should be no need for the feed inorganic carbon concentration to be known for determination of carbonate acid neutralisation capacity as the neutralising carbon component is determined from the difference in $\mathrm{CO}_{2}+\mathrm{CO}$ emission at 1000 and 450 or $500{ }^{\circ} \mathrm{C}$. Further development of this methodology for this system will focus on measurement of the $\mathrm{CO}_{2}+\mathrm{CO}$ emission at $500{ }^{\circ} \mathrm{C}$ in $\mathrm{N}_{2}$ carrier gas with a view to make the determination of $\mathrm{ANC}_{\text {therm-carb }}$ independent of siderite concentration. It is noted that validation and optimisation would be required for other mineral systems and the effects of and corrections for organic carbon remain to be developed. 
Supplementary Materials: The following are available online at https:/ / www.mdpi.com/article/ $10.3390 / \mathrm{min} 11111181 / \mathrm{s} 1$, Table S1: Bulk assay concentrations for the single carbonate minerals samples (ppm unless stated otherwise), Table S2: Single carbonate $\mathrm{CO}_{2}$ and weight loss data for thermal decomposition in $\mathrm{O}_{2}$ carrier, Table S3: $\mathrm{CO}$ and $\mathrm{CO}_{2}$ emissions and weight loss for siderite thermal decomposition in $\mathrm{O}_{2}$ carrier gas, Table $\mathrm{S} 4$ : $\mathrm{CO}$ and $\mathrm{CO}_{2}$ emissions and weight loss for siderite thermal decomposition in $\mathrm{N}_{2}$ carrier gas.

Author Contributions: Conceptualisation, P.W.; Methodology, G.L. and A.R.G.; Validation, G.L. and M.H.-A.; Formal Analysis, G.L., M.H.-A. and A.R.G.; Investigation, A.R.G., P.W., R.S.C.S., G.L. and R.G.; Resources, G.L. and R.G.; Writing-Original Draft Preparation, A.R.G.; Writing-Review and Editing, P.W., R.S.C.S., G.L., R.G. and M.H.-A.; Administration, P.W. and R.G.; Funding Acquisition, P.W. and R.G. All authors have read and agreed to the published version of the manuscript.

Funding: Rio Tinto (2020-2021) funded this research and provided the mine site project waste samples.

Data Availability Statement: The data presented in this study are available in The Application of Thermal Decomposition for Determination of Carbonate Acid-Neutralising Capacity for Improved Acid Mine Drainage Prediction and associated Supplementary material.

Conflicts of Interest: R.G. and M.H.-A. declare conflict of interest in the choice of, and funding for, this research project, in the writing of this manuscript and in the decision to publish. No other conflict of interests are declared.

\section{References}

1. Naidu, G.; Ryu, S.; Thiruvenkatachari, R.; Choi, Y.; Jeong, S.; Vigneswaran, S. A critical review on remediation, reuse, and resource recovery from acid mine drainage. Environ. Pollut. 2019, 247, 1110-1124. [CrossRef] [PubMed]

2. INAP. Global Acid Rock Drainage Guide. 2010. Available online: http://www.gardguide.com/index.php/Main_Page (accessed on 13 October 2021).

3. Parbhakar-Fox, A.; Lottermoser, B.G. A critical review of acid rock drainage prediction methods and practices. Miner. Eng. 2015, 82, 107-124. [CrossRef]

4. $\quad$ Smart, R.S.C.; Skinner, W.M.; Levay, G.; Gerson, A.R.; Thomas, J.E.; Sobieraj, H.; Schumann, R.; Weisener, C.G.; Weber, P.A.; Miller, S.D.; et al. ARD Test Handbook: Project P387, A Prediction and Kinetic Control of Acid Mine Drainage; AMIRA International Ltd.: Melbourne, Australia, 2002.

5. INAP. 2009. Available online: http:/ / www.gardguide.com/index.php?title=Chapter_6\#6.6.7_Water_Cover_Methods (accessed on 13 October 2021).

6. Jambor, J.L.; Dutrizac, J.E.; Raudsepp, M.; Groat, L.A. Effect of peroxide on neutralization-potential values of siderite and other carbonate minerals. J. Environ. Qual. 2003, 32, 2373-2378. [CrossRef] [PubMed]

7. Weber, P.A.; Thomas, J.E.; Skinner, W.M.; Smart, R.S.C. Improved acid neutralisation capacity assessment of iron carbonates by titration and theoretical calculation. Appl. Geochem. 2004, 19, 687-694. [CrossRef]

8. Dyantyi, N. Application of Mineralogy in the Interpretation of Laboratory Scale Acid Rock Drainage (ARD) Prediction Tests: A Gold Case Study. Master's Thesis, University of Cape Town, Cape Town, South Africa, 2014.

9. Gerson, A.R.; Rolley, P.J.; Davis, C.; Feig, S.T.; Doyle, S.; Smart, R.S.C. Unexpected non-acid drainage from sulfidic rock waste. Sci. Rep. 2019, 9, 4357. [CrossRef] [PubMed]

10. Masindi, V.; Gitari, M.W.; Tutu, H.; DeBeer, M. Efficiency of ball milled South African bentonite clay for remediation of acid mine drainage. J. Water Process Eng. 2015, 8, 227-240. [CrossRef]

11. Beck, C.W. Differential thermal analysis curves of carbonate minerals. Am. Mineral. 1950, 35, 985-1013.

12. García, A.C.; Latifi, M.; Chaouki, J. Kinetics of calcination of natural carbonate minerals. Miner. Eng. 2020, 150, 106279. [CrossRef]

13. Cuthbert, F.L.; Rowland, R.A. Differential thermal analysis of some carbonate minerals. Am. Mineral. 1947, 32, 111-116.

14. Rowland, R.A. Differential thermal analysis of clays and carbonates. Clays Clay Technol. 1952, 1, 151-163. [CrossRef]

15. Tian, L.; Tahmasebi, A.; Yu, J. An experimental study of the thermal decomposition behaviour of magnesite. J. Therm. Anal. Calorim. 2014, 118, 1577-1584. [CrossRef]

16. Hammack, R.W. Evolved-gas analysis: A method for determining pyrite, marcasite, and alkaline-earth carbonates. In Environmental Geochemistry of Sulfide Oxidation; Alpers, C.N., Blowes, D.W., Eds.; American Chemical Society: Washington, DC, USA, 1994; Volume 550, pp. 431-444.

17. LaCount, R.B.; Anderson, R.R.; Friedman, S.; Blaustein, B.D. Sulphur in coal by programmed-temperature oxidation. Fuel 1987, 66, 909-913. [CrossRef]

18. LaCount, R.B.; Kern, D.G.; King, W.P.; LaCount, R.B.J.; Miltz, D.J.J.; Stewart, A.L.; Trulli, T.K.; Walker, D.K.; Wicker, R.K. Advances in coal characterization by programmed-temperature oxidation. Fuel 1993, 72, 1203-1208. [CrossRef]

19. Dubrawski, J.V.; Warnes, S.S.J. Use of differential scanning calorimetry in measuring the thermal decomposition of mineral carbonates occurring in coal. Fuel 1987, 66, 1733-1736. [CrossRef] 
20. Kern, D.; LaCount, R.B.; Hammack, R.W. Improving the acid-base account by use programmed temperature oxidation and evolved gas analysis. In Proceedings of the 21st West Virginia Surface Mine Drainage Task Force Symposium, Morgantown, WV, USA, 4-5 April 2000.

21. Kemp, S.J.; Wagner, D.; Mounteney, I. Low Level Detection and Quantification of Carbonate Species Using Thermogravimetric and Differential Thermal Analysis; British Geological Survey: Nottingham, UK, 2010; p. 35.

22. Geelhoed, J.S.; Meeussen, J.C.L.; Hillier, S.; Lumsdon, D.G.; Thomas, R.P.; Farmer, J.G.; Paterson, E. Identification and geochemical modeling of processes controlling leaching of $\mathrm{Cr}(\mathrm{VI})$ and other major elements from chromite ore processing residue. Geochim. Cosmochim. Acta 2002, 66, 3927-3942. [CrossRef]

23. Takeno, N. Atlas of Eh-pH Diagrams Intercomparison of Thermodynamic Databases; Geological Survey of Japan Open File Report No.419; National Institute of Advanced Industrial Science and Technology: Tokyo, Japan, 2005. 